Original article

Red Beetroot Thematic Issue

\title{
Thermal Stability of Betalains in By-Products of the Blanching and Cutting of Beta vulgaris $\mathbf{L}$. var conditiva
}

\author{
Carlos M. Otálora ${ }^{1}$, Evelyn L. Bonifazi ${ }^{2}$, Eliana N. Fissore ${ }^{1}$, María F. Basanta ${ }^{1}$, Lía N. Gerschenson ${ }^{1 *}$ \\ ${ }^{1}$ Universidad de Buenos Aires (UBA), Facultad de Ciencias Exactas y Naturales, \\ Departamento de Industrias and National Research Council of Argentina (CONICET); \\ Instituto de Tecnología de Alimentos y Procesos Químicos (ITAPROQ). Ciudad Universitaria, \\ Avenida Intendente Guiraldes 2620, (1428) CABA, Argentina \\ ${ }^{2}$ UMYMFOR-CONICET, Facultad de Ciencias Exactas y Naturales, \\ University of Buenos Aires, Ciudad Universitaria, (1428) CABA, Argentina
}

Key words: red beetroot, blanching, cutting, by-products, betalains thermal stability

The objective of this study was to evaluate the thermal stability $\left(5^{\circ} \mathrm{C}, 25^{\circ} \mathrm{C}\right.$, and $\left.45^{\circ} \mathrm{C}\right)$ of betalains present in by-products of the blanching and cutting of Beta vulgaris L. var conditiva, to evaluate the possibility of taking advantage of them as a source of natural colorants to be incorporated in food products. The identification of the betalain compounds present in these by-products was also performed. Blanching waters showed pigment degradation at all the temperatures evaluated. The remnant tissues were freeze dried rendering beetroot powders whose pigments only presented thermal degradation at $45^{\circ} \mathrm{C}$. Sixteen betalain compounds were identified in powders by chromatography and it was concluded that a thermal treatment at $45^{\circ} \mathrm{C}$ during six days affected the chemical stability of some of these compounds, producing a diversity of betalain degradation products. Results obtained allowed concluding that the red beetroot powder would have a better performance as a natural coloring additive than the blanching water at temperatures below $45^{\circ} \mathrm{C}$. Probably, the low water activity of the powder and its lignin content ensured an effective protection of the pigments up to this temperature.

\section{INTRODUCTION}

The concern for healthy eating has driven the search for more natural ingredients and additives. As part of this reality, the use of natural pigments in food industrialization has been extended.

Natural pigments are extracted from plant tissues rich in such compounds as betalains, anthocyanins, carotenoids, and chlorophylls. Red beet (Beta vulgaris L. var conditiva) contains betacyanins and betaxanthins that are characterized by the presence of betalamic acid in their chemical structure [Polturak \& Aharoni, 2018; Sakuta, 2014; Stintzing et al., 2002]. The betacyanins $(\mathrm{Bc})$ are a source of red-violet color with $\lambda_{\max }$ of absorption spectrum at $530 \mathrm{~nm}$ [Saenz et al., 2012] whereas betaxanthins $(\mathrm{Bx})$ provide food with yellow-orange color having a $\lambda_{\text {max }}$ of absorption spectrum at $470 \mathrm{~nm}$ [Khan $\&$ Giridhar, 2015]. More than $80 \%$ of the red pigments in beet are betacyanins, mainly betanin (betanidin $5-O$ - $\beta$-glucoside) and its isomer isobetanin [Nemzer et al., 2011; Sawicki et al., 2016]. In addition, there are approximately 15 natural betaxanthins in red beet, with vulgaxanthin I and indicaxanthin being the main ones [Khan \& Giridhar, 2015].

\footnotetext{
* Corresponding Author: Tel.: +54 1152859014 ;

E-mail: lia@di.fcen.uba.ar (L.N.Gerschenson)
}

The stability of betalains is affected by different factors, such as temperature, $\mathrm{pH}$, water activity, light, presence or absence of oxygen, and enzymatic action [Celli \& Brooks, 2017; Herbach et al., 2006; Wybraniec \& Mizrahi, 2005]. Betacyanins in beet extracts have been noted as having $\mathrm{pH}$ stability in the range of 3-7 [Mikołajczyk-Bator \& Czapski, 2017] and to be readily susceptible to thermal degradation [Gengatharan et al., 2016]. Temperatures above $50^{\circ} \mathrm{C}$ are reported to produce the loss of color and antioxidant capacity. In the heat treatment, the betacyanins can be degraded by isomerization and/or decarboxylation [Kumorkiewicz \& Wybraniec, 2017]. A slight hypsochromic and hypochromic change can occur displacing the maximum absorption in the spectrum, therefore imparting an orange-red color [Azeredo, 2009]. Also, betanin and isobetanin can be dehydrogenated and hydrolyzed causing the formation of neobetanin (4, 15-dehydrobetanin), which is bright yellow [Herbach et al., 2006]. On the other hand, betaxanthins are also thermally sensitive and have a lower stability than betacyanins do [Pires Goncalves et al., 2013].

In the food area, betalains application is accepted by the European Community [2008] and these pigments (named E162) are used in the production of jellies, jams, strawberry yogurt, ice cream, fruit cocktails, candies, and cookies [Esatbeyoglu et al., 2015]. 
Plant by-products are promising sources of high-value compounds with antioxidant and/or antimicrobial properties, such as fibers and polyphenols [O'Shea et al., 2012]. Red beet processing generates large quantities of underutilized biomass [Fernandez et al., 2017]. Bengardino et al. [2019] studied the extraction of bioactive compounds from beet leaves for the valorization of this by-product.

Red beet roots are consumed fresh, fermented, dried or after thermal processing. Polyphenol oxidase (PPO) and peroxidase (POX) are present in plant tissues and during preservation and storage of food products based on red beets, these enzymes are responsible for changes in color and nutritive value. For the reduction of enzymes activity, in general, a blanching treatment is applied in the frame of raw material industrialization [Latorre et al., 2012]. It is also usual to subject these tissues to cutting and trimming to give them the desired geometrical characteristics [Jideani et al., 2017]. Blanching and cutting give the origin to remnant water and solids that can give rise to additives and ingredients to be used in the food industry itself.

The objective of this study was to evaluate the thermal stability of betalains present in by-products of the blanching and cutting of Beta vulgaris roots, to evaluate the possibility of taking advantage of them as a source of natural colorants to be applied in food products. The identification of the betalain compounds present in these by-products was performed as well.

\section{MATERIALS AND METHODS}

\section{Chemicals}

Chemicals used were of analytical quality and provided by Sigma-Aldrich (Saint Louis, USA) or Merck Química (Buenos Aires, Argentina). The solvents for chromatography were of HPLC quality. Deionized water was used (Milli- ${ }^{\mathrm{TM}}$, Billerica, MA, USA).

\section{Plant material}

Samples of beet (Beta vulgaris L. var conditiva) roots were obtained from local markets in Buenos Aires city (Argentina).

\section{Obtaining beet root by-products}

Red beets were washed, peeled, and cut into slices $1 \mathrm{~cm}$ thick, $4.9 \mathrm{~cm}$ to $6.0 \mathrm{~cm}$ in diameter. Slices were subjected to a blanching treatment by immersion in water at $90^{\circ} \mathrm{C}$ for $7 \mathrm{~min}$ with a tissue/water ratio of $0.5 \mathrm{~kg} / \mathrm{L}$ according to Latorre et al. [2010]. The remnant water was frozen $\left(-18^{\circ} \mathrm{C}\right)$. The tissues were considered equivalent to those from the cutting operation in the industrialization and were also frozen at $-18^{\circ} \mathrm{C}$. Their water was sublimated in a Pennsalt freeze dryer (Pennsalt, Philadelphia, USA) at a chamber pressure of $100 \mathrm{~mm}$ and shelf temperature of $25^{\circ} \mathrm{C}$. They were then milled in a domestic blade mill (DeLonghi, Buenos Aires, Argentina) and sieved to obtain powders with a particle size smaller than $105 \mu \mathrm{m}$.

The peroxidase and polyphenol oxidase activities in the powders were evaluated according to Latorre et al. [2010] and expressed as absorbance unit/( $\min \times \mathrm{mg}$ protein $)$.

\section{Chemical analysis of cell wall components in beetroot powders}

Uronic acids, total (non-cellulosic) carbohydrates, cellulose, lignin, and protein contents were evaluated in red beet powders, according to $\mathrm{Ng}$ et al. [1998] by means of sulfuric acid hydrolysis. From the final residues, cellulose and lignin were determined gravimetrically, whilst the non-cellulosic carbohydrates, uronic acid as well as protein contents were determined in supernatants with the methods reported by Dubois et al. [1956], Filisetti-Cozzi et al. [1991], and Lowry et al. [1951], respectively.

\section{Moisture content and water activity of beetroot powders}

Moisture content of the powders was determined, in duplicate, by means of and infrared scale (Moisture Analyzer MB45 Ohaus Corporation, New Jersey, USA), using a $\approx 0.500 \mathrm{~g}$ sample.

Water activity was measured two times at $25^{\circ} \mathrm{C}$ in a Decagon AquaLab (Series 3 Water Activity Meter, Pullman, WA, USA), as explained by Basanta et al. [2016].

\section{Evaluation of thermal stability of betalains in beetroot by-products}

The powder was fractionated in amounts of $\approx 3.000 \mathrm{~g}$ in caramel glass flasks (volume $30 \mathrm{~mL}$ ) and stored, for 6 days, at $5^{\circ} \mathrm{C}, 25^{\circ} \mathrm{C}$, and $45^{\circ} \mathrm{C}$. In the case of blanching water $(\mathrm{pH}=6.3), \approx 2.00 \mathrm{~mL}$ were stored for 4 days in the same type of flasks, at the same temperatures. Storage was performed in duplicate.

After each storage day, the samples were characterized for their UV/Vis spectrum, total betalains content, and color parameters.

\section{Betalain extraction and quantification}

For the powder characterization, a quantity of $\approx 0.5000 \mathrm{~g}$ was extracted with $15 \mathrm{~mL}$ of Milli-Q $\mathrm{Q}^{\mathrm{TM}}$ water, stirred for $2 \mathrm{~h}$, and centrifuged at $7700 \times g$ and $4^{\circ} \mathrm{C}$ for $15 \mathrm{~min}$ (Eppendorf 5804R, Hamburg, Germany). The supernatant was separated and used for measurement. In the case of blanching water, the measurement was performed directly on the sample.

According to Moßhammer et al. [2006], powder extracts obtained or blanching water were diluted in McIlvaine buffer $(\mathrm{pH}=6.5)$ to adjust the maximum absorption at $1.00 \pm 0.05$ at wavelengths of $536 \mathrm{~nm}$ (betacyanins) or $476 \mathrm{~nm}$ (betaxanthins). The measurement was carried out in a UV-mini 1240UV-VIS spectrophotometer (Shimadzu, Kyoto, Japan). The content of betacyanins (Bc) and betaxanthins (Bx) was calculated as:

$$
\mathrm{Bc} \text { or } \mathrm{Bx}=[(\mathrm{A} \times \mathrm{DF} \times \mathrm{Mw} \times 100 / \varepsilon \times 1)]
$$

where: $\mathrm{A}$ is the absorption value of the betanin at its $\lambda_{\text {max }}$ of $536 \mathrm{~nm}$ or vulgaraxanthin at its $\lambda_{\max }$ of $476 \mathrm{~nm}$, corrected by the absorption at $600 \mathrm{~nm}$; DF is the dilution factor and 1 is the pathlength $(1 \mathrm{~cm})$ of the cuvette; $\mathrm{Mw}$ is the molecular weight of betanin $(550 \mathrm{~g} / \mathrm{mol})$ or vulgaraxanthin I $(339 \mathrm{~g} / \mathrm{mol})$; and $\varepsilon$ is the molar extinction coefficient of betanin $(60,000 \mathrm{~L} /$ $(\mathrm{mol} \times \mathrm{cm}))$ or vulgaraxanthin $(48,000 \mathrm{~L} /(\mathrm{mol} \times \mathrm{cm}))$. 
The contents of betacyanins and betaxanthins were expressed as $\mathrm{mg} / 100 \mathrm{~g}$ for powder and as $\mathrm{mg} / \mathrm{L}$ for blanching water.

Determinations were performed three times, and average and standard deviation (SD) are reported.

\section{Absorption spectra}

The spectra were determined for the extracts obtained from powders as described in the Betalain extraction and quantification section or directly on blanching water. Both were previously diluted with Milli- $\mathrm{Q}^{\mathrm{TM}}$ water to adjust the absorption maximum to $1.00 \pm 0.05$. The whole visible spectrum (300-700 nm) was recorded at constant intervals $(\Delta \lambda=2 \mathrm{~nm})$ using a UV-mini 1240UV-VIS spectrophotometer (Shimadzu, Kyoto, Japan) and $2 \mathrm{~mm}$ pathlength glass cells.

\section{Color}

Measurement of powders and water color was performed with a Minolta colorimeter (Minolta CM-600 Co. Ltd., Osaka, Japan) with natural daylight illuminant D65 and standard observer angle $\alpha: 10^{\circ}$. Each sample was placed on a white tile, registering the color through the chromatic coordinates of the CIELab space, $L^{*}$ (ranging from 0, black, to 100, white), $a^{*}$ (positive values for reddish colors and negative values for greenish ones), and $b^{*}$ (positive for yellowish colors and negative for the bluish ones).

The average and SD for triplicate measurements are reported.

\section{Chromatographic analysis of betalains in beetroot powders}

To clarify the mechanism of betalains degradation, a chromatographic analysis was performed for beetroot powders at $45^{\circ} \mathrm{C}$.

\section{Extraction of betalains}

A quantity of $\approx 1.0 \mathrm{~g}$ of powder was extracted twice with $10 \mathrm{~mL}$ of methanol/water $(80: 20, v / v)$ under continuous agitation, then centrifuged at $7700 \times g$ and $4^{\circ} \mathrm{C}$ for $15 \mathrm{~min}$ (Eppendorf 5804R, Hamburg, Germany). The supernatants were mixed and concentrated to a final volume of $2 \mathrm{~mL}$, under reduced pressure at room temperature $\left(25^{\circ} \mathrm{C}\right)$, then filtered through a $0.45 \mu \mathrm{m}$ nylon filter and directly analyzed by HPLC [Swarna et al., 2013].

\section{HPLC-DAD analysis}

HPLC-DAD analyses of the extracts were performed with a Waters HPLC 1525 system (Waters, Milford, USA), equipped with a binary pump system (model M0925P), a degasser (model M09DG2 455M), and with a photodiode array detector (model A10998). An Eclipse XDB-C18 column (150 mm x $4.6 \mathrm{~mm}, 5 \mu \mathrm{m}$ particle size, Agilent, USA), with a mobile phase of formic acid (1 mL/100 mL water) (A) and acetonitrile (B) [Swarna et al., 2013], at $0.3 \mathrm{~mL} / \mathrm{min}$ flow rate and $20 \mu \mathrm{L}$ injection volume was used in the study. A linear gradient was used, starting with $1 \% \mathrm{~B}$ and up till reaching $33 \%$ after 40 minutes. Chromatograms were recorded at 470 and $530 \mathrm{~nm}$ which correspond to the betaxanthins and betacyanins maximum absorption wavelengths.

\section{HPLC-ESI-MS-MS analysis}

HPLC-ESI-MS/MS analyses were performed with an Agilent 1200 HPLC system (Agilent Technologies, Wilmington, USA) provided with a binary pump (model G1312B), an automatic injector (model G1367D), a degasser (model G1379B), and a photodiode array detector (model G1315C) registering the chromatograms at $470 \mathrm{~nm}$ and $530 \mathrm{~nm}$. The HPLC system was coupled with a high-resolution mass spectrometer Bruker micrOTOF-QII (Bruker Daltonics, Billerica, MA, USA) with an electrospray ionization source (ESI). The ionization conditions were $200^{\circ} \mathrm{C}$ and $4.5 \mathrm{kV}$ for the capillary temperature and voltage, respectively. The nitrogen pressure as the nebulizer gas and its flow rate as the drying gas, was 3.0 bar and $6.0 \mathrm{~L} / \mathrm{min}$, respectively. The mass scan was performed between 50 and $950 \mathrm{~m} / \mathrm{z}$ in positive mode. The acquisition and processing of data were done using the software Bruker Compass Data Analysis ver. 4.0 (Bruker Daltonics, Billerica, MA, USA). Peak identification was carried out by means of the UV spectra and mass spectra with identification of the $[\mathrm{M}+\mathrm{H}]^{+}$ions of the individual compounds, as well as their fragmentation.

\section{Statistical analysis}

Results are reported as average and SD. The number of replicates is stated for each analysis. The comparison of the results was carried out by means of an analysis of variance, ANOVA, with the level of significance at $\alpha=0.05$. The Tukey test was used "a posteriori" [Sokal \& Rohlf, 2000].

Statistical analysis was performed using the Prism 5 utility (Statistical Software for Windows GraphPad, La Jolla, USA).

\section{RESULTS AND DISCUSSION}

\section{Efficiency of blanching treatment}

It is important to note that the results obtained in relation to the activity of POX and PPO (Figure 1) showed that the blanching method used was effective in inhibiting the activity of both enzymes. Therefore, the results reported below are not affected by them.

\section{Chemical composition and physicochemical characteristics of the by-products}

The powder was obtained with an average size $<105 \mu \mathrm{m}$ and a yield of $12.3 \mathrm{~g} / 100 \mathrm{~g}$ tissue. The low moisture content $(4.9 \mathrm{~g} / 100 \mathrm{~g}$ powder) and a water activity of 0.28 guarantees the stability against deterioration during storage [Muggeridge \& Clay, 2001].

Lightness $\left(L^{*}\right)$ of the powder was low $(23.1 \pm 0.1)$ and $a^{*}(33.3 \pm 0.1)$ and $b^{*}(3.9 \pm 0.3)$ color coordinates were both above zero, with $a^{*}$ being higher than $b^{*}$, which is coincident with the red color visually observed.

Non-cellulosic carbohydrates (hemicelluloses and pectins) were the main powder components $(30.9 \mathrm{~g} / 100 \mathrm{~g})$ and, of them, $9.8 \mathrm{~g} / 100 \mathrm{~g}$ were constituted by uronic acids. The rest of the components included proteins $(8.5 \mathrm{~g} / 100 \mathrm{~g})$, lignin $(1.7 \mathrm{~g} / 100 \mathrm{~g})$, and cellulose $(7.0 \mathrm{~g} / 100 \mathrm{~g})$ (Table 1). It is worth noticing that, due to the technique used to obtain beetroot powders, water-soluble pectin and other residual water-soluble components belonging to the cytoplasmic medium (i.e. 

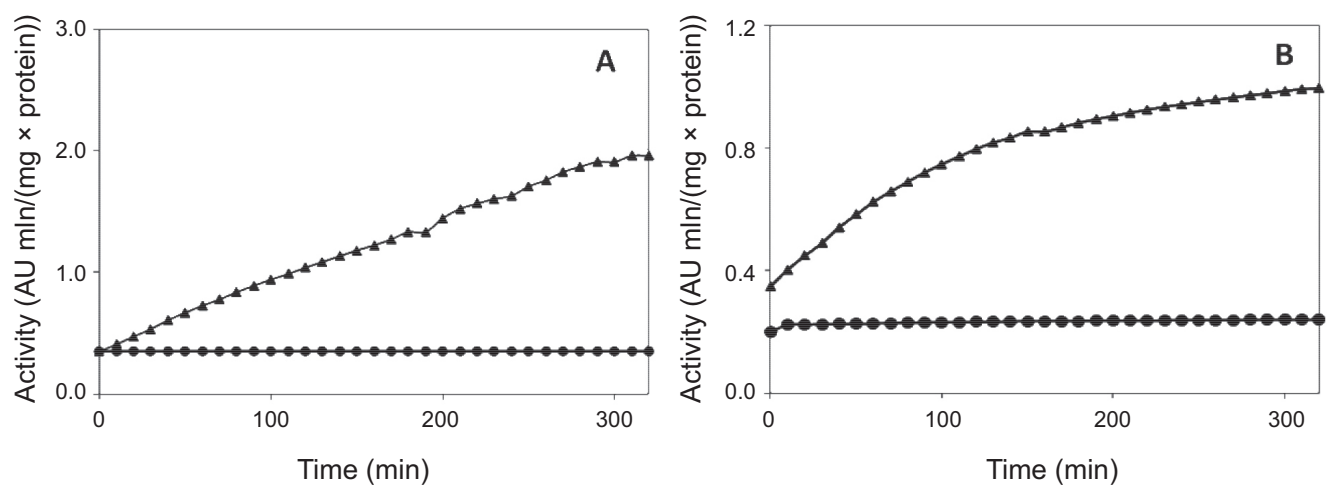

FIGURE 1. Efficiency of blanching procedure for enzymes inactivation.

(A) Peroxidase activity. (B) Polyphenol oxidase activity. AU: Absorbance unit.

Non-blanched tissues.

Blanched tissues.

TABLE 1. Chemical composition of the red beetroot powder prior to storage at different temperatures.

\begin{tabular}{lc}
\hline Component & Content \\
\hline Moisture $(\mathrm{g} / 100 \mathrm{~g})$ & $4.9 \pm 0.1$ \\
Cellulose $(\mathrm{g} / 100 \mathrm{~g})$ & $7.0 \pm 0.1$ \\
Non-cellulosic carbohydrates $(\mathrm{g} / 100 \mathrm{~g})$ & $30.9 \pm 0.8$ \\
Uronic acids $(\mathrm{g} / 100 \mathrm{~g})$ & $9.8 \pm 0.8$ \\
Proteins $(\mathrm{g} / 100 \mathrm{~g})$ & $8.5 \pm 0.4$ \\
Lignin $(\mathrm{g} / 100 \mathrm{~g})$ & $1.7 \pm 0.1$ \\
Betacyanins $(\mathrm{mg}$ betanin/100 g) & $0.47 \pm 0.01$ \\
Betaxanthins (mg vulgaxanthin/100 g) & $0.26 \pm 0.01$ \\
\hline
\end{tabular}

Results are presented as mean $\pm \mathrm{SD}(\mathrm{n}=2)$. Values are reported per $100 \mathrm{~g}$ of powder.

globular proteins, amino acids, mono and di-saccharides) might have been lost during the procedure applied [Vincken et al., 2003].

It can be observed in Table 1 that the powders had a higher content of betacyanins than betaxanthins $(0.47 \mathrm{mg}$ betanin/100 g vs. $0.26 \mathrm{mg}$ vulgaxanthin/100 g), which is coincident with the trend observed for color parameters $a^{*}$ and $b^{*}$. Betalains are found in the vacuoles of plant cells belonging to the order of Caryophyllales [Polturak \& Aharoni, 2018]. According to Wiczkowski et al. [2018] and Sepúlveda-Jiménez et al. [2004], red beetroot accumulates mainly betacyanins in the form of betanin which is found at high concentration in the root $(0.5 \mathrm{~g} / \mathrm{kg}$ of betanin).

In the case of blanching water $(\mathrm{pH} 6.3)$, the $L^{*}$ showed values of $25 \pm 1$ and the $a^{*}(50 \pm 1)$ and $b^{*}(37 \pm 3)$ parameters were positive, with $a^{*}$ being higher than $b^{*}$. The concentration was $5.57 \pm 0.56 \mathrm{mg}$ betanin/L for betacyanins and $5.36 \pm 0.38 \mathrm{mg}$ vulgaxanthin /L for betaxanthins.

\section{Thermal stability of betalains in beetroot by-products}

\section{UV/Visible spectra}

Figure 2 (A, B and C) shows the UV/Visible spectra, in a wavelength range between $300 \mathrm{~nm}$ and $700 \mathrm{~nm}$, for beet- root powder extracts stored at $5^{\circ} \mathrm{C}, 25^{\circ} \mathrm{C}$, and $45^{\circ} \mathrm{C}$. The wavelengths where the peaks of maximum absorption occurred were $470 \mathrm{~nm}$ and $530 \mathrm{~nm}$, corresponding to the absorption of betaxanthins and betacyanins, respectively. Similar spectrophotometric behavior was reported by other authors [Cejudo et al., 2014; Cejudo-Bastante et al., 2014; Stintzing \& Carle, 2004]. All the extracts showed that the peak at $530 \mathrm{~nm}$ had a higher absorbance than the peak at $470 \mathrm{~nm}$. The temperature exerted a null effect when the systems were stored at temperatures of $5^{\circ} \mathrm{C}$ and $25^{\circ} \mathrm{C}$. Nevertheless, the absorbance values for the maximum wavelengths decreased throughout storage at $45^{\circ} \mathrm{C}$, revealing the effect of this temperature on betalain stability.

In the case of blanching waters stored at the three temperatures, it can be observed (Figure 2D, E and F) that the peak at $470 \mathrm{~nm}$ showed greater absorbance than the peak at $530 \mathrm{~nm}$. During storage at $5^{\circ} \mathrm{C}$, it was observed that the peak at $470 \mathrm{~nm}$ decreased with storage time. At storage temperatures of $25^{\circ} \mathrm{C}$ and $45^{\circ} \mathrm{C}$, it was observed a strong decay of both peaks with time and the decay increased with temperature. Khan \& Giridhar [2014] stated that the degradation of betalains accelerated with increasing temperature and heating period.

\section{Content of betalains}

Figure 3 (A and B) shows the content of betacyanins and betaxanthins in red beetroot powders. For each storage time at different temperatures, the content of betacyanins was greater than the one of betaxanthins. The betalains were found to be much more stable at $5^{\circ} \mathrm{C}$ and $25^{\circ} \mathrm{C}$ with losses of less than $1 \%$ during storage time. Cai \& Corke [2000] also studied the stability of betalains in amaranth powders, establishing that the stability of betalains increases as the dry matter increases and with a moisture content below 5\%. Serris $\&$ Biliaderis [2001] reported that the stability of these pigments increases with lower water activity. In the present work, the red beetroot powders presented a moisture content lower than $4.9 \mathrm{~g} / 100 \mathrm{~g}$ and a water activity of 0.28 , facts that can justify the high stability of betacyanins and betaxanthins at $5^{\circ} \mathrm{C}$ and $25^{\circ} \mathrm{C}$. It must be also considered that lignin was detected in the beetroot powder (Table 1), which can act as an antioxidant, protecting pigments from degradation [You et al., 2019]. However, the content of betalains, varied during storage time at $45^{\circ} \mathrm{C}$. A loss of $60 \%$ was observed for the be- 

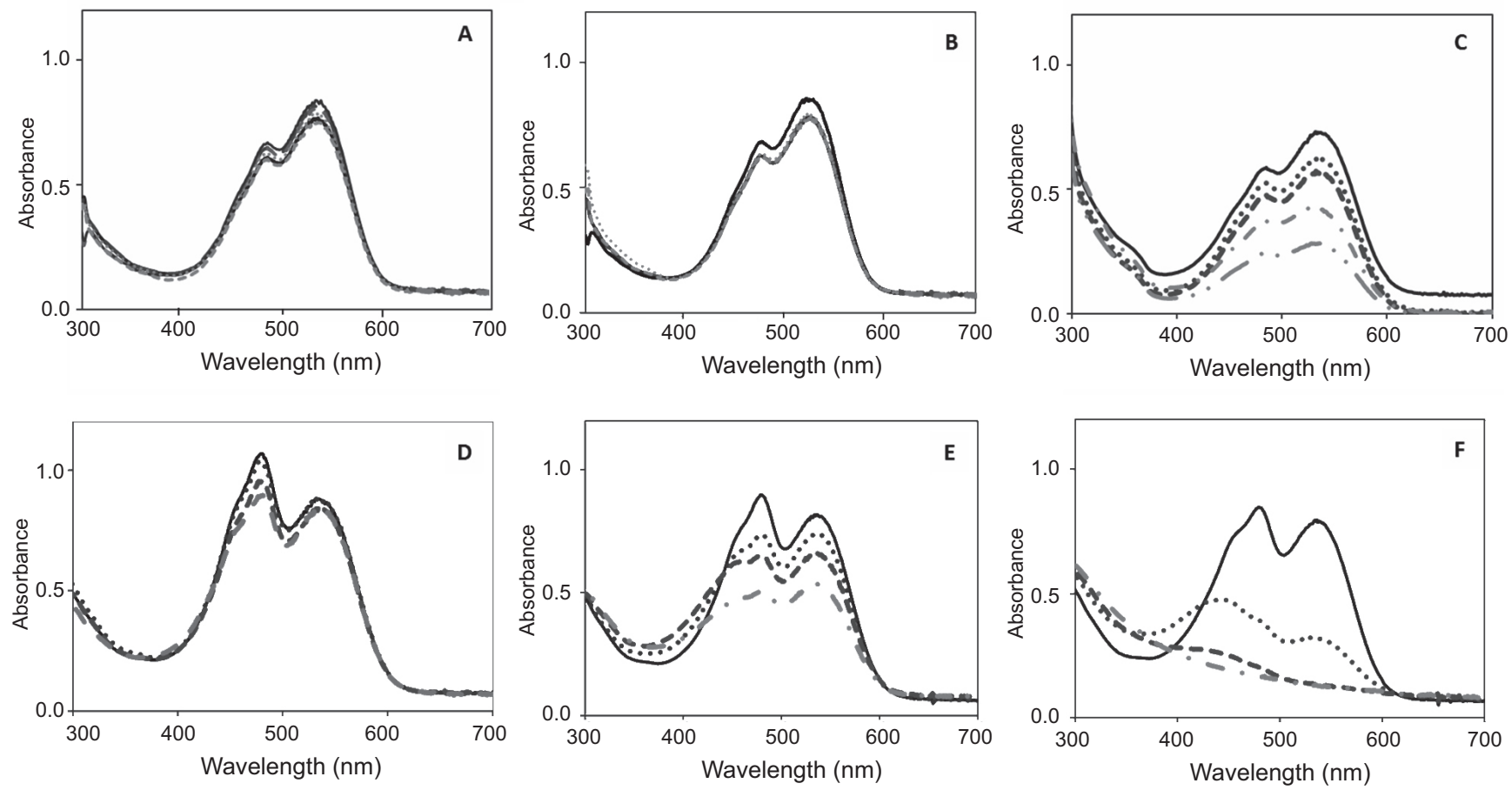

FIGURE 2. UV/Visible spectra at different storage temperatures.

Powder stored at $5^{\circ} \mathrm{C}(\mathrm{A}), 25^{\circ} \mathrm{C}(\mathrm{B}), 45^{\circ} \mathrm{C}(\mathrm{C})$. Blanching water stored at $5^{\circ} \mathrm{C}(\mathrm{D}), 25^{\circ} \mathrm{C}(\mathrm{E}), 45^{\circ} \mathrm{C}(\mathrm{F})$. Time: —— day $0, \cdots \cdots \cdots \cdots \cdot$ day $1,---$ day 2 , $\cdot-\cdot-\cdot$ day $4, \cdot-\cdot \cdot \cdot \cdot$ day 6.
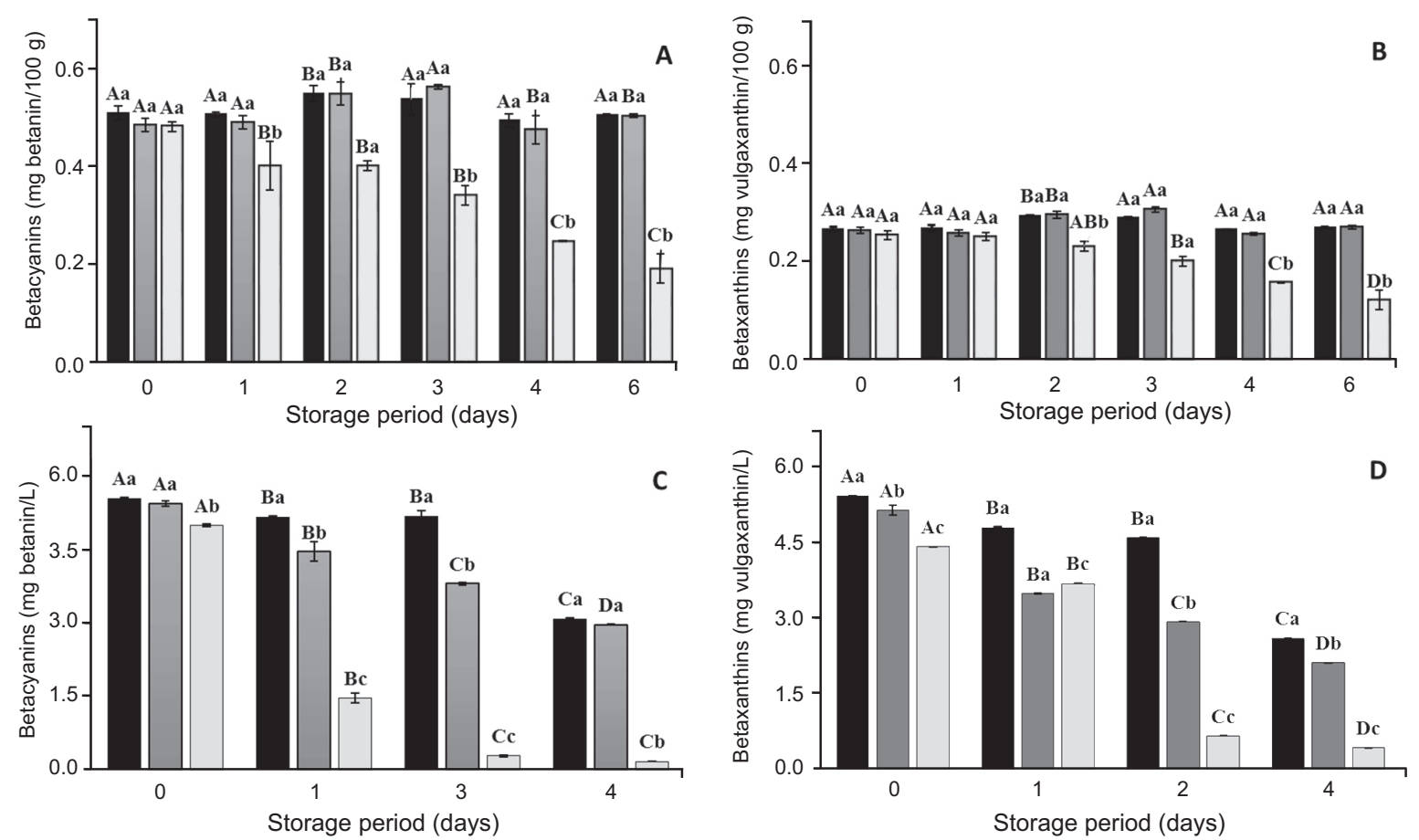

FIGURE 3. Betalain content at different storage temperatures.

Betacyanins in powder (A). Betaxanthins in powder (B). Betacyanins in blanching water (C). Betaxanthins in blanching water (D). Storage temperatures: $5^{\circ} \mathrm{C} ; 25^{\circ} \mathrm{C} ; 45^{\circ} \mathrm{C}$. Results are presented as mean $\pm \mathrm{SD}(\mathrm{n}=3)$. Different lower case letters indicate significant differences $(\mathrm{p}<0.05)$ between storage temperatures. Different capital letters indicate significant differences $(p<0.05)$ between storage days. 

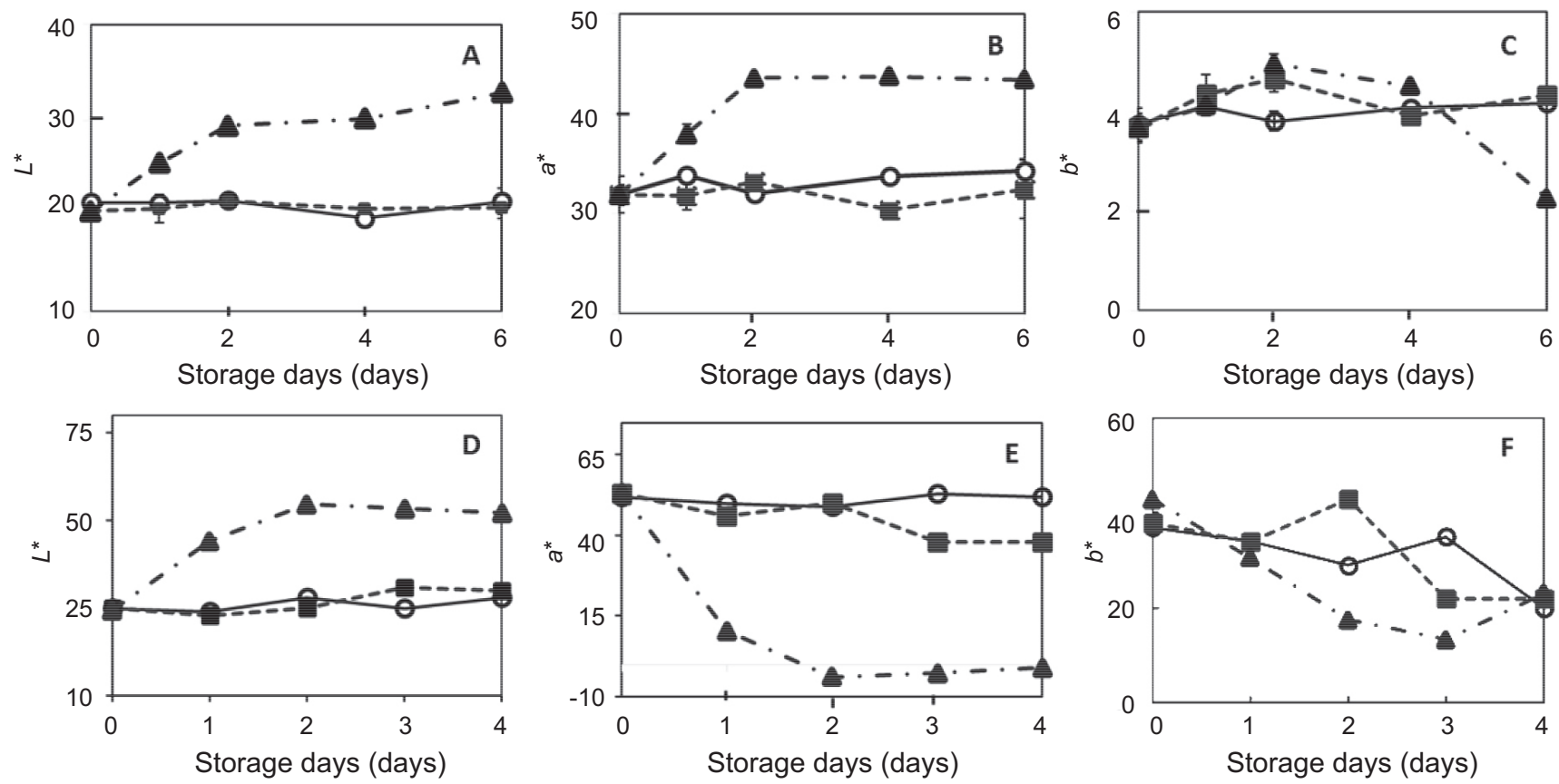

FIGURE 4. Color parameters at different storage temperatures.

Powder: $L^{*}(\mathrm{~A}), a^{*}(\mathrm{~B}), b^{*}(\mathrm{C})$. Blanching water: $L^{*}(\mathrm{D}), a^{*}(\mathrm{E}), b^{*}(\mathrm{~F})$. Storage temperatures: $\mathrm{O} 5^{\circ} \mathrm{C}$

$25^{\circ} \mathrm{C} ; \boldsymbol{\Delta} 45^{\circ} \mathrm{C}$

tacyanins and 53\% for betaxanthins, showing that these compounds were unstable at this higher temperature.

In the case of blanching water, the betalains concentration was affected by all the three temperatures studied, as can be observed in Figure $3(\mathrm{C}$ and $\mathrm{D})$. The losses observed were $44 \%$ (betacyanins) and $52 \%$ (betaxanthins) at $5^{\circ} \mathrm{C}, 45 \%$ (betacyanins) and $59 \%$ (betaxanthins) at $25^{\circ} \mathrm{C}$ as well as $97 \%$ (betacyanins) and $90 \%$ (betaxanthins) at $45^{\circ} \mathrm{C}$. Cai et al. [1998] reported a higher stability of pigments in amaranth powders compared to aqueous solutions, attributing this trend to the lower water activity of the powders.

\section{Color parameters}

The CIELab color parameters $\left(L^{*}, a^{*}, b^{*}\right)$ are reported in Figure 4. The powders stored at $5^{\circ} \mathrm{C}, 25^{\circ} \mathrm{C}$, and $45^{\circ} \mathrm{C}$ (Figure $4 \mathrm{~A}, \mathrm{~B}$ and $\mathrm{C}$ ) showed high values for the $a^{*}$ parameter, which is expressed as a strongly red color of the powders. At $5^{\circ} \mathrm{C}$ and $25^{\circ} \mathrm{C}$ there was practically no variation in the color parameters with storage time. During storage at $45^{\circ} \mathrm{C}$, an increase for $L^{*}$ and $a^{*}$ was observed, in contrast with a decrease for $b^{*}$ parameter. It can be concluded that the color stability of the powders was not affected during storage at $5^{\circ} \mathrm{C}$ and $25^{\circ} \mathrm{C}$ but was in fact affected when the powders were stored at $45^{\circ} \mathrm{C}$. This trend matches the ones observed for spectra and betacyanins and betaxanthins content which varied significantly during storage time at $45^{\circ} \mathrm{C}$.

In the case of blanching water (Figure $4 \mathrm{D}, \mathrm{E}$ and $\mathrm{F}$ ), only the parameter $b^{*}$ showed a clear trend to a decrease at $5^{\circ} \mathrm{C}$. At $25^{\circ} \mathrm{C}$, both $a^{*}$ and $b^{*}$ decreased and, at $45^{\circ} \mathrm{C}, L^{*}$ increased while both $a^{*}$ and $b^{*}$ decreased showing negative values for parameter $a^{*}$ at the higher storage times which means a change from red to green color.

It can be concluded from the studies of spectra, pigment concentration and color parameters, that the changes suffered by blanching waters with storage time at $5^{\circ} \mathrm{C}, 25^{\circ} \mathrm{C}$ and $45^{\circ} \mathrm{C}$ are greater than those occurring in beetroot powders. While blanching waters showed changes at all temperatures tested, the powders only suffered changes at $45^{\circ} \mathrm{C}$. This can be ascribed to their low water activity and to the presence of lignin of the cell wall material which can diminish, by means of its antioxidant activity, the pigments oxidation at $5^{\circ} \mathrm{C}$ and $25^{\circ} \mathrm{C}$. As a consequence, among the products evaluated, the powders would have a better performance as a natural coloring additive than the blanching waters at temperatures below $45^{\circ} \mathrm{C}$.

Therefore, it is interesting to clarify the changes suffered by betalains present in powders during storage at $45^{\circ} \mathrm{C}$ to have a more complete picture of the mechanisms involved in their decay as well as of their potential as coloring additives.

\section{HPLC-DAD-ESI-MS/MS analysis of the betalains in beetroot powders}

The betalain compounds of beetroot powders non stored (I) and stored at $45^{\circ} \mathrm{C}$ for 6 days (II), were evaluated by HPLC-DAD and HPLC-MS/MS, to analyze the effect of temperature on these pigments contained in a solid matrix. The results are shown in Figure 5. The compounds were identified by comparing their retention times (tr) and MS/MS spectra with bibliographic information [Herbach et al., 2004; Nemzer et al., 2011; Sawicki et al., 2016].

From the analysis of the HPLC-DAD chromatograms registered at 470 and $530 \mathrm{~nm}$ wavelength, it was confirmed that these powders contained betacyanins, with a maximum absorbance in the visible spectrum at $530 \mathrm{~nm}$ being responsible for the intense red color, and compounds of the family of betaxanthins, with a maximum absorbance at $470 \mathrm{~nm}$.

Within the family of betaxanthins (Figure 5 and Table 2, $\mathrm{I}-470 \mathrm{~nm}$ ), vulgaxanthin I (glutamine bx) corresponding to 


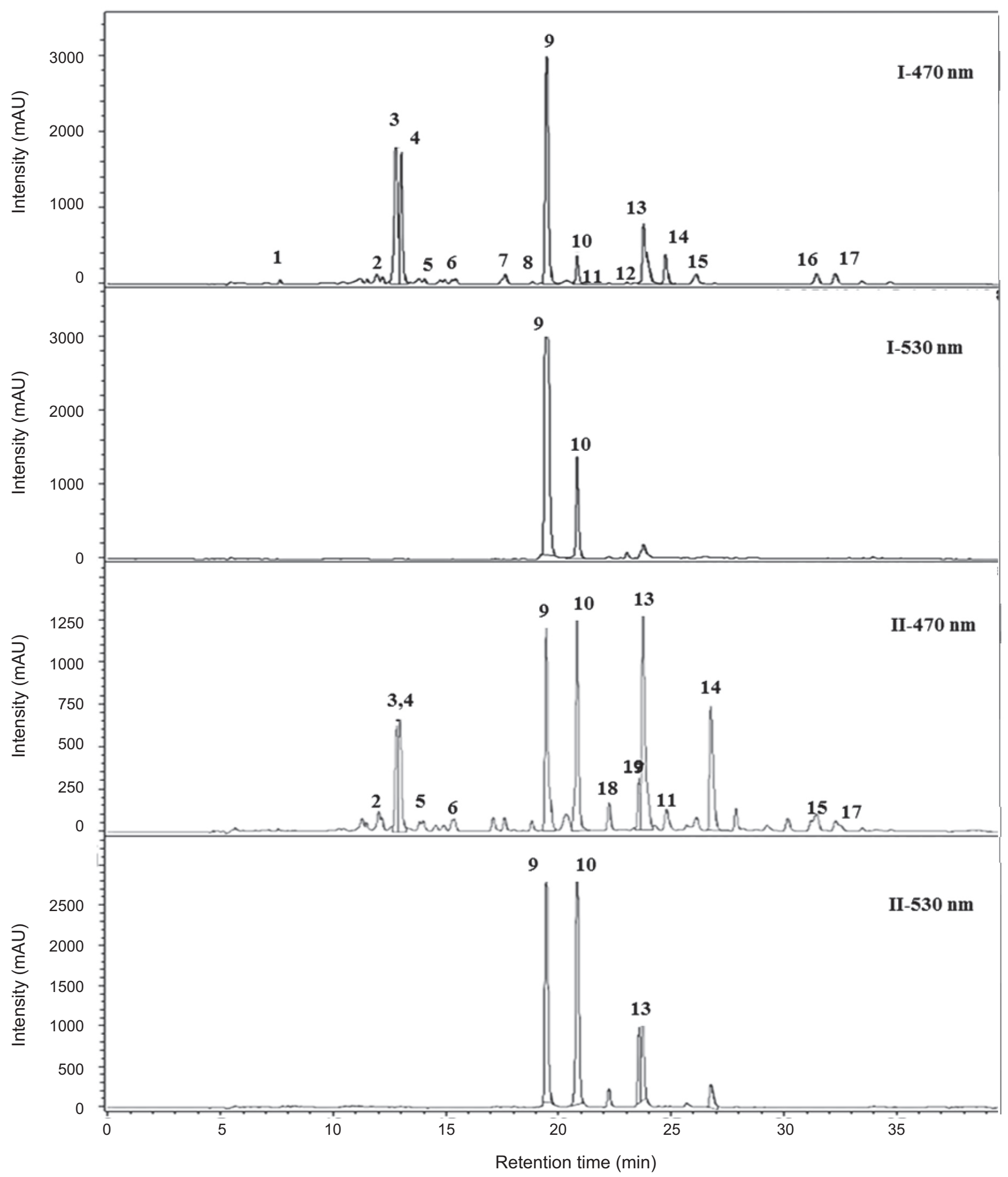

FIGURE 5. HPLC chromatograms of the betalain compounds present in powders.

Non-heat-treated (I) and $45^{\circ} \mathrm{C}$ heat-treated powders (II). The detection was performed at $470 \mathrm{~nm}$ and $530 \mathrm{~nm}$. mAU: one-thousandth of an absorbance unit.

peak 3 and 4 was found through the pseudomolecular ions $[\mathrm{M}+\mathrm{H}]^{+}$at retention times of 12.8 and 13 min both with $m / z 340.11\left(\mathrm{C}_{14} \mathrm{H}_{18} \mathrm{~N}_{3} \mathrm{O}_{7}\right)$. The MS/MS spectra showed two characteristic fragments, one at $m / z, 323.09[\mathrm{M}+\mathrm{H}-17]^{+}$ that could be formed by the elimination of hydroxyl group, and another at $m / z, 277.08[323-46]^{+}$originated by decar- boxylation and di-deprotonation [Sawicki et al., 2016]. It can be inferred that these two compounds (peaks 3 and 4) that present the same $\lambda_{\max }$, and MS/MS spectra, are the two possible diasteroisomers of vulgaxanthin I due to the different configurations that $\mathrm{C} 11$ can adopt. According to the literature [Kujala et al., 2002; Mégard, 1993; Singer \& von Elbe, 
TABLE 2. Analysis of the betalamic compounds by HPLC-DAD and HPLC-ESI- MS/MS of the non-heat-treated (I) and $45^{\circ} \mathrm{C}$ heat-treated powders (II).

\begin{tabular}{|c|c|c|c|c|c|c|c|c|}
\hline \multicolumn{2}{|c|}{ Peak no. } & \multirow{2}{*}{ Betalain name } & \multirow{2}{*}{ Chemical formula } & \multicolumn{2}{|c|}{$\begin{array}{l}\text { Retention } \\
\text { time (min) }\end{array}$} & \multirow{2}{*}{$\lambda_{\max }(\mathrm{nm})$} & \multirow{2}{*}{$\begin{array}{c}m / z \\
\mathrm{MS}[\mathrm{M}+\mathrm{H}]^{+}\end{array}$} & \multirow{2}{*}{$\begin{array}{l}m / z \mathrm{MS} / \mathrm{MS} \\
\text { of }[\mathrm{M}+\mathrm{H}]^{+}\end{array}$} \\
\hline $\mathbf{I}$ & II & & & I & II & & & \\
\hline 1 & - & $\begin{array}{l}\text { Asparagine bx } \\
\text { (Vulgaxantin III) }\end{array}$ & $\mathrm{C}_{13} \mathrm{H}_{16} \mathrm{~N}_{3} \mathrm{O}_{7}$ & 7.8 & - & 471 & 326.10 & - \\
\hline 2 & 2 & Serine bx & $\mathrm{C}_{12} \mathrm{H}_{15} \mathrm{~N}_{2} \mathrm{O}_{7}$ & 11.9 & 11.8 & 470 & 299.09 & - \\
\hline $\mathbf{3 , 4}$ & 3 & $\begin{array}{c}\text { Glutamine bx } \\
\text { (Vulgaxanthin I) }\end{array}$ & $\mathrm{C}_{14} \mathrm{H}_{18} \mathrm{~N}_{3} \mathrm{O}_{7}$ & $12.8 / 13$ & 12.8 & 470 & 340.11 & $\begin{array}{l}323.09 \\
277.08\end{array}$ \\
\hline 5 & 5 & $\begin{array}{l}\text { 2,17-Bidecarboxy-2,3- } \\
\text {-dehydro-neobetanin }\end{array}$ & $\mathrm{C}_{22} \mathrm{H}_{23} \mathrm{~N}_{2} \mathrm{O}_{9}$ & 14 & 14 & 463 & 459.16 & 330.11 \\
\hline 6 & 6 & $\begin{array}{l}\text { Glutamic acid bx } \\
\text { (Vulgaxanthin II) }\end{array}$ & $\mathrm{C}_{14} \mathrm{H}_{17} \mathrm{~N}_{2} \mathrm{O}_{8}$ & 14.9 & 15 & 471 & 341.10 & $\begin{array}{l}194.04 \\
150.06\end{array}$ \\
\hline 7 & - & $\gamma$-Aminobutyric acid bx & $\mathrm{C}_{13} \mathrm{H}_{17} \mathrm{~N}_{2} \mathrm{O}_{6}$ & 17.5 & - & 463 & 297.11 & - \\
\hline 8 & - & $\begin{array}{c}\text { Proline bx } \\
\text { (Indicaxanthin) }\end{array}$ & $\mathrm{C}_{14} \mathrm{H}_{17} \mathrm{~N}_{2} \mathrm{O}_{6}$ & 18.7 & - & 477 & 309.11 & - \\
\hline 9,10 & 9,10 & Betanin /Isobetanin & $\mathrm{C}_{24} \mathrm{H}_{27} \mathrm{~N}_{2} \mathrm{O}_{13}$ & $19.5 / 20.8$ & $19.5 / 20.8$ & 536 & 551.15 & 389.09 \\
\hline 11 & 11 & $\begin{array}{l}\text { Dopamine bx } \\
\text { (Miraxanthin V) }\end{array}$ & $\mathrm{C}_{17} \mathrm{H}_{19} \mathrm{~N}_{2} \mathrm{O}_{6}$ & 21.8 & 24.8 & 456 & 347.12 & $\begin{array}{l}303.13 \\
211.07 \\
137.06\end{array}$ \\
\hline 12 & - & Tyrosine bx (Portulacaxanthin II) & $\mathrm{C}_{18} \mathrm{H}_{19} \mathrm{~N}_{2} \mathrm{O}_{7}$ & 22.8 & - & 472 & 375.12 & $\begin{array}{l}211.08 \\
178.07\end{array}$ \\
\hline 13 & 13 & $\begin{array}{l}\text { 4,15-Dehydro- betanin } \\
\text { (Neobetanin ) }\end{array}$ & $\mathrm{C}_{24} \mathrm{H}_{25} \mathrm{~N}_{2} \mathrm{O}_{13}$ & 23.8 & 23.9 & 464 & 549.13 & 387.07 \\
\hline 14 & 14 & Valine bx & $\mathrm{C}_{14} \mathrm{H}_{18} \mathrm{~N}_{2} \mathrm{O}_{6}$ & 24.6 & 26.8 & 466 & 311.12 & $\begin{array}{l}267.13 \\
221.13 \\
193.13 \\
150.05\end{array}$ \\
\hline 15 & 15 & $\begin{array}{c}\text { Leucine bx } \\
\text { (Vulgaxanthin IV) }\end{array}$ & $\mathrm{C}_{15} \mathrm{H}_{21} \mathrm{~N}_{2} \mathrm{O}_{6}$ & 26.2 & 31.9 & 470 & 325.14 & 281.15 \\
\hline 16 & - & Phenylalanine bx & $\mathrm{C}_{18} \mathrm{H}_{19} \mathrm{~N}_{2} \mathrm{O}_{6}$ & 31.2 & - & 470 & 359.12 & - \\
\hline 17 & 17 & Tryptophan bx & $\mathrm{C}_{20} \mathrm{H}_{20} \mathrm{~N}_{3} \mathrm{O}_{6}$ & 32.1 & 32.2 & 472 & 398.13 & - \\
\hline- & 18 & 17-Decarboxy-betanin & $\mathrm{C}_{23} \mathrm{H}_{27} \mathrm{~N}_{2} \mathrm{O}_{11}$ & - & 20.8 & 515 & 507.16 & 345.11 \\
\hline- & 19 & 2-Decarboxy-neobetanin & $\mathrm{C}_{22} \mathrm{H}_{25} \mathrm{~N}_{2} \mathrm{O}_{11}$ & - & 21.9 & a & 505.15 & 343.09 \\
\hline
\end{tabular}

a: $\lambda_{\max }$ was not determined due to co-elution with another compound or to low concentration. PI: Peak number corresponding to the chromatogram I-470/530 nm (non-heat-treated). PII: Peak number corresponding to the chromatogram II-470/530 $\mathrm{nm}\left(45^{\circ} \mathrm{C}\right.$ heat-treated powders).

1980 ], the predominant yellow pigment in red beetroot juice is vulgaxanthin I. There could also be identified, serina bx, vulgaxanthin II, III and IV, isoindicaxanthin and miraxanthin V, but in a lower proportion. This family of compounds presented fragmentations that correspond to the loss of amino acids, desamination, and decarboxylation.

Betacyanins (Figure 5 and Table 2, I-530 nm) were detected at retention times of 19.5 and 20.8 min (peaks 9 and 10) and were identified as betanin and isobetanin [Sawicki et al., 2016; Wybraniec, 2007], showing the pseudomolecular ion $[\mathrm{M}+\mathrm{H}]^{+}$at $m / z$ 551.15 $\left(\mathrm{C}_{24} \mathrm{H}_{27} \mathrm{~N}_{2} \mathrm{O}_{13}\right)$ and in the MS/MS spectrum, a characteristic fragment at $m / z, 389.09[\mathrm{M}+\mathrm{H}-$ $162]^{+}$which was formed by the loss of the glucose molecule resulting in the presence of aglycones [betanidin $+\mathrm{H}]^{+}$or [isobetanidin $+\mathrm{H}]^{+}$. Neobetanin was also found (I-470 nm, peak 13), with a $\lambda_{\max }$ of $464 \mathrm{~nm}$ because it has an extra double bond, which changes the resonance, generating a $\lambda_{\max }$ shift. In the mass spectrum, it gave an origin to the $[\mathrm{M}+\mathrm{H}]^{+}$ion at $m / z, 549.13$ and in the MS/MS spectrum to a fragment at $\mathrm{m} / \mathrm{z} 387.07$, also formed by the loss of the glucose molecule, characteristic rupture of these compounds [Sawicki et al., 2016].

Comparing the information for the non-heat-treated (I) and the heat-treated (II) powders (Figure 5 and Table 2), it can be observed that peaks $1,7,8,12$, and 16 corresponding to asparagine bx, $\gamma$-aminobutyric acid bx, proline/Iso bx, tirosine bx, and phenylalanine bx, respectively, did not appear in the heat-treated samples, showing that some betaxanthins are highly sensitive to temperature. In addition, two new compounds derived from betacyanins appeared (peaks 18 and 19). Peak 18 corresponded to 17-decarboxy-betanin giving the pseudomolecular ion $[\mathrm{M}+\mathrm{H}]^{+}$at $m / z, 507.16$ and an MS/ MS fragment at $m / z, 345.11(507-162)$ and $\lambda_{\max }$ of $515 \mathrm{~nm}$. Peak 19 corresponded to 2-decarboxy-neobetanin, with $[\mathrm{M}+\mathrm{H}]^{+}$at $m / z$ 505.15 and an MS/MS fragment at $m / z 343.09$ (505-162) and resulted from decarboxylation of neobetanin (549-44). 17-Decarboxy-betanin was the product of the decarboxylation of betanin (551-44). Decarboxylation is induced by the thermal effect as it was reported by Herbach et al. [2004]. The displacement of the maximum absorbance 
of 17-decarboxy-betanin ( $\lambda_{\max }$ of $515 \mathrm{~nm}$ ) with respect to the one of betanin/isobetanin ( $\lambda_{\max }$ of $536 \mathrm{~nm}$ ) was produced by the delocalization of electrons $\pi$ due to the decarboxylation of the C17 [Minale et al., 1965; Stintzing et al., 2004]. Previous studies on red beetroot showed that decarboxylations can occur in the $\mathrm{C} 2, \mathrm{C} 15$, and $\mathrm{C} 17$ although these positions differ in their susceptibility [Herbach et al., 2004; Wybraniec, 2007; Wybraniec \& Mizrahi, 2005].

Analyzing the ratio of the isobetanin/betanin and neobetanin/betanin areas for the non-heat-treated and the heat-treated powders (Figure 5), it could be observed an increase in the isobetanin/betanin ratio after the heat treatment (from 0.25 to 1) due to isomerization of betanin to isobetanin by the thermal effect [Herbach et al., 2004]. On the other hand, for the neobetanin/betanin ratio, its increase was found to be non-significant (from 0.21 to 0.25 ).

\section{CONCLUSIONS}

The thermal stability at 5,25 , and $45^{\circ} \mathrm{C}$ of betalains present in by-products of the blanching and cutting of Beta vulgaris tissues has been studied.

Blanching waters showed pigment degradation at all the temperatures evaluated. The red beetroot powders suffered pigments thermal degradation only at $45^{\circ} \mathrm{C}$. This can be ascribed to their low water activity and to the presence of lignin which can protect pigments from degradation, through its antioxidant activity, allowing to use these powders as a coloring additive up to $45^{\circ} \mathrm{C}$.

Chromatographic studies showed that storage at $45^{\circ} \mathrm{C}$ for six days, affected the chemical stability of betalains. Degradation reactions might impair the use of these powders as natural pigments in foods that are heat treated at temperatures higher than $45^{\circ} \mathrm{C}$ after pigment inclusion in the formulation.

It is expected that the results of this research will contribute to the addition of value to the Beta vulgaris tissues, thus contributing to its integral use as well as to the development of both sustainable processing technologies and healthy foods.

\section{RESEARCH FUNDING}

This study was financially supported by University of Buenos Aires (UBACyT 20020100100726/2011-2014 and 20020130100550BA/2014-2017), National Agency of Scientific and Technical Research (PICT 2015-2109 and 2013-2088), and CONICET (PIP 11220090100531/2010-2012 and 11220120100507/2013-2015).

\section{REFERENCES}

1. Azeredo, H.M. (2009). Betalains: properties, sources, applications, and stability-a review. International Journal of Food Science \& Technology, 44(12), 2365-2376.

2. Basanta, M.F., Marin, A., De Leo, S.A., Gerschenson, L.N., Erlejman, A.G., Tomás-Barberán, F.A., Rojas, A.M. (2016). Antioxidant Japanese plum (Prunus salicina) microparticles with potential for food preservation. Journal of Functional Foods, 24, 287-296.
3. Bengardino, M.B., Fernandez, M.V., Nutter, J., Jagus, R.J., Agüero, M.V. (2019). Recovery of bioactive compounds from beet leaves through simultaneous extraction: Modelling and process optimization. Food and Bioproducts Processing, 118, 227-236.

4. Cai Y.Z., Corke, H. (2000). Production and properties of spraydried amaranthus betacyanin pigments. Journal of Food Science, 65(7), 1248-1252.

5. Cai, Y., Sun, M., Corke, H. (1998). Colorant properties and stability of amaranthus betacyanin pigments. Journal of Agricultural and Food Chemistry, 46(11), 4491-4495.

6. Cejudo-Bastante, M.J., Hurtado, N., Mosquera, N., Heredia, F.J. (2014). Potential use of new Colombian sources of betalains. Color stability of ulluco (Ullucus tuberosus) extracts under different $\mathrm{pH}$ and thermal conditions. Food Research International, 64, 465-471.

7. Celli, G.B., Brooks, M.S.L. (2017). Impact of extraction and processing conditions on betalains and comparison of properties with anthocyanins - A current review. Food Research International, 100, SI, 501-509.

8. Dubois, M., Gilles, K.A., Hamilton, J.K., Rebers, P.A., Smith, F. (1956). Colorimetric method for determination of sugars and related substances. Analytical Chemistry, 28(3), 350-356.

9. Esatbeyoglu, T., Wagner, A.E., Schini-Kerth, V.B., Gerald Rimbach, G. (2015). Betanin - A food colorant with biological activity. Molecular Nutrition \& Food Research, 59, 36-47.

10. European Community. (2008). Regulation (EC) No $1333 / 2008$ of the European Parliament and of the Council of 16 December 2008 on food additives. Official Journal of the European Union, L354, 16-33.

11. Fernández, M.V., Jagus, R., Agüero, M. (2017). Evaluation and characterization of nutritional, microbiological and sensory properties of beet greens. Acta Scientific Nutritional Health, 1(3), $37-45$.

12. Filisetti-Cozzi, T.M.C.C., Carpita, N.C. (1991). Measurement of uronic acids without interference from neutral sugars. Analytical Biochemistry, 197(1), 157-162.

13. Gengatharan, A., Dykes, G.A., Choo, W.S. (2016). Stability of betacyanin from red pitahaya (Hylocereus polyrhizus) and its potential application as a natural colourant in milk. International Journal of Food Science \& Technology, 51 (2), 427-434.

14. Herbach, K.M., Stintzing, F.C., Carle, R. (2004). Impact of thermal treatment on color and pigment pattern of red beet (Beta vulgaris L.) preparations. Journal of Food Science, 69(6), C491- C498.

15. Herbach, K.M., Rohe, M., Stintzing, F.C., Carle, R. (2006). Structural and chromatic stability of purple pitaya (Hylocereus polyrhizus [Weber] Britton \& Rose) betacyanins as affected by the juice matrix and selected additives. Food Research International, 39(6), 667-677.

16. Jideani, A.I.O., Anyasi, T.A., Mchau, G.R.A., Udoro, E.O., Onipe, O.O. (2017). Processing and preservation of fresh-cut fruit and vegetable products. In I. Kahramanoglu (Ed.), Postharvest Handling. IntechOpen Limited, London, UK. Published online. DOI: 10.5772/intechopen.69763.

17. Khan, M.I., Giridhar, P. (2015). Plant betalains: Chemistry and biochemistry. Phytochemistry, 117, 267-295.

18. Khan, M.I., Giridhar, P. (2014). Enhanced chemical stability, chromatic properties and regeneration of betalains in Rivina humilis L. berry juice. LWT - Food Science and Technology, 58(2), 649-657. 
19. Kujala, T., Vienola, M., Klika, K., Loponen, J., Pihlaja, K. (2002). Betalain and phenolic compositions of four beetroot (Beta vulgaris) cultivars. European Food Research and Technology, 214(6), 505-510.

20. Kumorkiewicz, A., Wybraniec, S. (2017). Thermal degradation of major gomphrenin pigments in the fruit juice of Basella alba L.(Malabar spinach). Journal of Agricultural and Food Chemistry, 65(34), 7500-7508.

21. Latorre, M.E., Narvaiz, P., Rojas, A.M., Gerschenson, L.N. (2010). Effects of gamma irradiation on bio-chemical and physico-chemical parameters of fresh-cut red beet (Beta vulgaris L. var. conditiva) root. Journal of Food Engineering, 98(2), 178-191.

22. Latorre, M.E., Bonelli, P.R., Rojas, A.M., Gerschenson, L.N. (2012). Microwave inactivation of red beet (Beta vulgaris L. var. conditiva) peroxidase and polyphenoloxidase and the effect of radiation on vegetable tissue quality. Journal of Food Engineering, 109(4), 676-684.

23. Lowry, O.H., Rosebrough, N.J., Farr, A.L., Randall, R.J. (1951). Protein measurement with the Folin phenol reagent. Journal of Biological Chemistry, 193(1), 265-275.

24. Mégard, D. (1993). Stability of red beet pigments for use as food colorant: a review. Foods \& Food Ingredients Journal, 158, 130-150.

25. Mikołajczyk-Bator, K., Czapski, J. (2017). Effect of pH changes on antioxidant capacity and the content of betalain pigments during the heating of a solution of red beet betalains. Polish Journal of Food and Nutrition Sciences, 67(2), 123-128.

26. Minale, L., Piattelli, M., Nicolaus, R.A. (1965). Pigments of centrospermae-IV: On the biogenesis of indicaxanthin and betanin in Opuntia ficus-indica Mill. Phytochemistry, 4(4), 593-597.

27. Moßhammer, M.R., Stintzing, F.C., Carle, R. (2006). Evaluation of different methods for the production of juice concentrates and fruit powders from cactus pear. Innovative Food Science \& Emerging Technology, 7(4), 275-287.

28. Muggeridge, M., Clay, M. (2001). Quality specifications for herbs and spices. In K.V. Peter (Ed.), Handbook of Herbs and Spices, Volume 1, Woodhead Publishing, Cambridge, UK, pp. 13-21.

29. Nemzer, B., Pietrzkowski, Z., Spórna, A., Stalica, P., Thresher, W., Michałowski, T., Wybraniec, S. (2011). Betalainic and nutritional profiles of pigment-enriched red beet root (Beta vulgaris L.) dried extracts. Food Chemistry, 127(1), 42-53.

30. Ng, A., Parr, A. J., Ingham, L.M., Rigby, N.M., Waldron, K.W. (1998). Cell wall chemistry of carrots (Daucus carota Cv. Amstrong) during maturation and storage. Journal of Agricultural and Food Chemistry, 46(8), 2933-2939.

31. O'Shea, N., Arendt, E.K., Gallagher, E. (2012). Dietary fibre and phytochemical characteristics of fruit and vegetable by-products and their recent applications as novel ingredients in food products. Innovative Food Science \& Emerging Technologies, 16, 1-10.

32. Pires Goncalvez, L.C., Martorelli Di Genova, B., Dorr, F.A., Pinto, E., Leite Bastos, E. (2013). Effect of dielectric microwave heating on the color and antiradical capacity of betanin. Journal of Food Engineering, 118(1), 49-55.

33. Polturak, G., Aharoni, A. (2018). "La Vie En Rose": Biosynthesis, sources, and applications of betalain pigments. Molecular Plant, 11(1), 7-22.
34. Saenz, C., Cancino, B., Robert, P. (2012). Red betalains from Opuntia spp.: Natural colorants with potential applications in foods. Israel Journal of Plant Sciences, 60(3), 291-299.

35. Sakuta, M. (2014). Diversity in plant red pigments: anthocyanins and betacyanins. Plant Biotechnology Reports, 8(1), SI, 37-48.

36. Sawicki, T., Bączek, N., Wiczkowski, W. (2016). Betalain profile, content and antioxidant capacity of red beetroot dependent on the genotype and root part. Journal of Functional Foods, 27, 249-261.

37. Sepúlveda-Jiménez, G., Rueda-Benítez, P., Porta, H., Rocha-Sosa, M. (2004). Betacyanin synthesis in red beet (Beta vulgaris) leaves induced by wounding and bacterial infiltration is preceded by an oxidative burst. Physiological and Molecular Plant Pathology, 64(3), 125-133.

38. Serris, G.S., Biliaderis, C.G. (2001). Degradation kinetics of beetroot pigment encapsulated in polymeric matrices. Journal of the Science of Food and Agriculture, 81 (8), 691-700.

39. Singer, J.W., Von Elbe, J.H. (1980). Degradation rates of vulgaxanthine-I. Journal of Food Science, 45(3), 489-491.

40. Sokal, R.R., Rohlf, J.B. (2000). Biometry. The Principles and Practice of Statistics in Biological Research. San Francisco: WH Freeman and Company, pp 253-380.

41. Stintzing, F.C., Carle, R. (2004). Functional properties of anthocyanins and betalains in plants, food, and in human nutrition. Trends in Food Science \& Technology, 15(1), 19-38.

42. Stintzing, F.C., Stintzing, A.S., Carle, R., Frei, B., Wrolstad, R.E. (2002). Color and antioxidant properties of cyanidin-based anthocyanin pigments. Journal of Agricultural and Food Chemistry, 50(21), 6172-6181.

43. Swarna, J., Lokeswari, T.S., Smita, M., Ravindhran, R. (2013). Characterisation and determination of in vitro antioxidant potential of betalains from Talinum triangulare (Jacq.) Willd. Food Chemistry, 141(4), 4382-4390.

44. Vincken, J.P., Schols, H.A., Oomen, R.J.F.J., McCann, M.C., U1vskov, P., Voragen, A.G.J., Visser, R.G.F. (2003). If homogalacturonan were a side chain of rhamnogalacturonan I. Implications for cell wall architecture. Plant Physiology, 132(4), 1781-1789.

45. Wiczkowski, W., Romaszko, E., Szawara-Nowak, D., Piskula, M.K. (2018). The impact of the matrix of red beet products and interindividual variability on betacyanins bioavailability in humans. Food Research International, 108, 530-538.

46. Wybraniec, S., Mizrahi, Y. (2005). Generation of decarboxylated and dehydrogenated betacyanins in thermally treated purified fruit extract from purple pitaya (Hylocereus polyrhizus) monitored by LC-MS/MS. Journal of Agricultural and Food Chemistry, 53(17), 6704-6712.

47. Wybraniec, S. (2007). A method for identification of diastereomers of 2-decarboxy-betacyanins and 2, 17-bidecarboxy-betacyanins in reversed-phase HPLC. Analytical and Bioanalytical Chemistry, 389(5), 1611-1621.

48. You, Y.L., Li, N., Han, X., Guo, J.L., Zhao, Y., Huang, W.D., Zhang, J.C. (2019). The effect of six phenolics acids and tannic acid on colour stability and the anthocyanin content of mulberry juice during refrigerated storage. International Journal of Food Science and Technology, 54(6), SI, 2141-2150.

Submitted: 30 August 2019. Revised: 10 November and 30 December 2019. Accepted: 10 January 2020. Published on-line: 5 February 2020 . 